\title{
PENGEMBANGAN SISTEM PENCARIAN PADA TUJUH KITAB HADIS MENGGUNAKAN ALGORITMA KNUTH-MORRIS-PRATT ${ }^{1}$ Desy Kartika Sari, ${ }^{2}$ Dwi Sakethi, ${ }^{3}$ Rizky Prabowo
}

\author{
Jurusan Ilmu Komputer, Fakultas MIPA, Universitas Lampung \\ J1. Prof. Dr. Soemantri Brodjonegoro No. 1 Bandar Lampung 35145 \\ ${ }^{1}$ kartikadeka3@gmail.com, ${ }^{2}$ dwijim@fmipa.unila.ac.id, ${ }^{3}$ rizky.prabowo@fmipa.unila.ac.id
}

\begin{abstract}
Hadith search information system requires the main function that is the word search method to make it easier for users to find the word they are looking for. Word search can be conducted by using string matching algorithm to obtain the search term, one of them is Knuth-Morris-Pratt algorithm. This algorithm has two stages in the search process, namely the pre-KMP process which is the stage of giving a shift value in the keyword (pattern) and KMP-Search stage which is a matching phase between text and keyword (pattern). The process of matching text and patterns is conducted from the left to the right based on the value of the shift that has been obtained in the pre-KMP process. The search time is influenced by the length of the text on the database and the pattern the user is looking for, the longer the text and pattern, the search time will increase.
\end{abstract}

Keywords: Hadith, Knuth-Morris-Pratt, String Matching

\section{Pendahuluan}

Sistem informasi yang dapat dirasakan manfaatnya saat ini seperti sistem pencarian (search engine). The American Heritage Dictionary mendefinisikan search engine sebagai sebuah program perangkat lunak (software) yang menelusur, menjaring, dan menampilkan informasi dari pangkalan data [1]. Data yang didapat oleh APJII (Asosiasi Penyelenggara Jasa Internet Indonesia), jumlah pengguna internet di Indonesia mencapai 132,7 juta pengguna atau sekitar $51,7 \%$ dari total jumlah penduduk Indonesia sebesar 256,2 juta jiwa pada tahun 2016. Perangkat yang digunakan untuk mengakses informasi dari internet yaitu smartphone, sebanyak 63,1 juta pengguna dan komputer sebanyak 2,2 juta pengguna, berdasarkan data tersebut penggunaan teknologi internet dan web saat ini membawa dampak yang signifikan dalam berbagai bidang termasuk bidang agama. Penggunaan mesin pencari dapat juga digunakan dalam bidang keislaman, misalnya pencarian ayat Alqur'an, pencarian do'a sehari-hari, dan pencarian hadis.

Hadis diperlukan sebagai pedoman hidup dalam ajaran umat muslim, dengan jumlah populasi penduduk muslim Indonesia pada tahun 2009 adalah 202.867 .000 jiwa atau setara dengan 12,9\% dari populasi muslim dunia [3], berdasarkan data banyaknya populasi penduduk muslim di Indonesia, maka diperlukan sistem pencarian informasi terkait pedoman hidup umat Islam yaitu Alqur'an dan Hadis.

Sistem informasi pencarian hadis memerlukan fungsi utama yaitu metode pencarian kata untuk mempermudah user menemukan kata yang dicarinya. Pencarian kata dapat dilakukan dengan memanfaatkan algoritma string matching untuk mendapatkan kata yang dicari, salah satunya yaitu algoritma Knuth-Morris-Pratt. Cara kerja algoritma ini adalah dengan mulai mencocokkan pattern pada awal teks. Kata dicocokkan mulai dari posisi kiri hingga akhirnya sampai pada posisi paling kanan, algoritma ini akan mencocokkan karakter per karakter pattern dengan karakter di teks yang bersesuaian, sampai salah satu kondisi berikut dipenuhi yaitu karakter di pattern dan di teks yang dibandingkan tidak cocok (mismatch) dan semua karakter di pattern cocok, kemudian algoritma akan memberitahukan penemuan di posisi ini. Algoritma kemudian menggeser pattern berdasarkan tabel shift, lalu mengulangi langkah dua sampai pattern berada di ujung teks $[2,4,5]$. Uraian yang telah dijelaskan mendasari peneliti untuk mencoba mengembangkan sistem pencarian kata pada tujuh kitab hadis menggunakan algoritma Knuth-Morris-Pratt. 


\section{Metodologi}

\section{Tahapan Penelitian}

Pengembangan sistem pencarian pada tujuh kitab hadis menggunakan algoritma Knuth-MorrisPratt ini dilakukan dengan beberapa langkah yaitu analisis kebutuhan, studi literatur, pengumpulan data, implementasi, dan pengujian. Tahapan penelitian dapat dilihat pada Gambar 1.

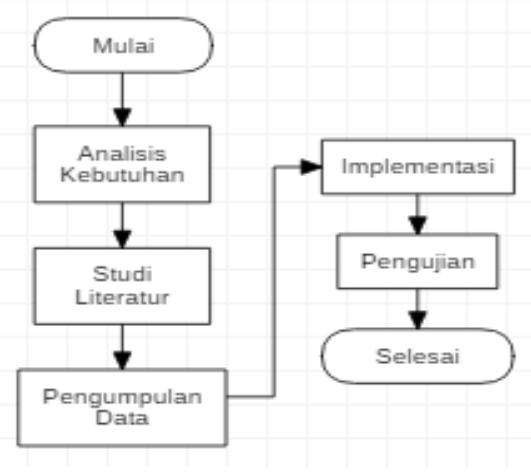

Gambar 1. Diagram Alur Penelitian.

\section{a. Analisis Kebutuhan}

Analisis kebutuhan dimulai dengan mengidentifikasi, mengumpulkan studi literatur mengenai metode-metode string matching khususnya algoritma Knuth-Morris-Pratt.

\section{b. Studi Literatur}

Studi literatur yang dilakukan pada penelitian ini berupa pengumpulan data yang dibutuhkan oleh sistem. Data-data yang dibutuhkan tersebut, diperoleh dari hasil melakukan pengamatan serta mempelajari catatan yang memuat data-data yang diperlukan terhadap permasalahan yang sedang diteliti. Metode studi literatur digunakan dengan melihat penelitian yang sudah ada dan merujuk pada penelitian yang telah dilakukan.

\section{c. Pengumpulan Data}

Data yang dibutuhkan pada penelitian ini yaitu data hadis yang diperoleh dari Al-Islam dan Hadist Bot yang dapat diakses menggunakan aplikasi Telegram.

\section{d. Implementasi}

Implementasi merupakan tahapan peneliti melakukan analisis terhadap cara kerja dari algoritma Knuth-Morris-Pratt serta mengimplementasikannya ke dalam sebuah program dengan menggunakan PHP dan MySQL dalam melakukan proses pencarian kata.

\section{e. Pengujian}

Tahap ini merupakan tahap pengujian dari keseluruhan tahap-tahap yang telah dilalui dimulai dari analisis kebutuhan hingga tahap implementasi. Algoritma diuji dengan melakukan proses pencarian kata pada data hadis dalam sistem. 


\section{Cara Kerja Algoritma Knuth-Morris-Pratt}

Algoritma Knuth-Morris-Pratt memiliki dua tahap pada proses pencariannya, yaitu tahap preKMP yang merupakan tahap pemberian nilai pergeseran pada masing-masing karakter yang dimasukkan (pattern) oleh user. Tahap kedua yaitu KMPSearch yang merupakan tahap pencocokkan karakter yang dimasukkan (pattern) oleh user dengan karakter yang ada pada database (text) berdasarkan nilai pergeseran. Flowchart dari pencarian menggunakan algoritma Knuth-Morris-Pratt dapat ditunjukkan pada Gambar 2.

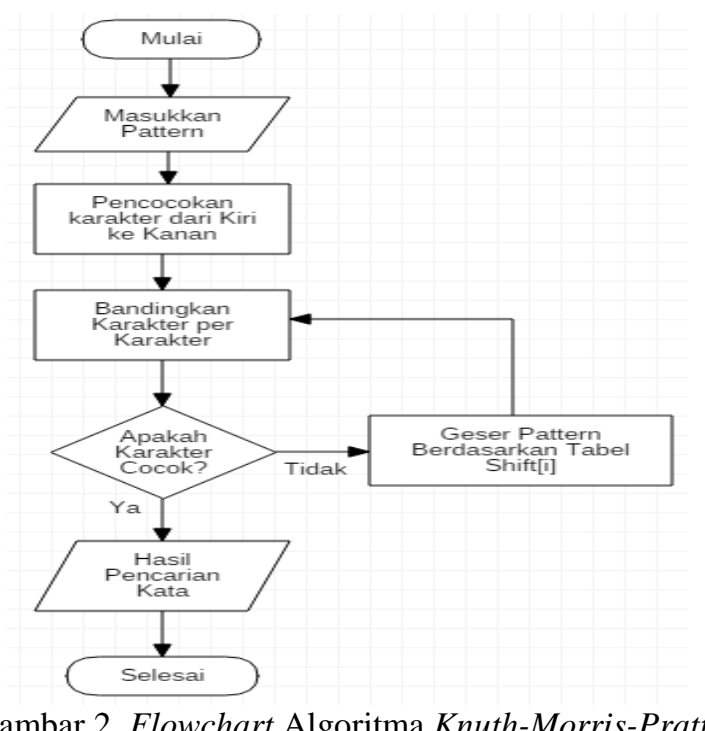

Gambar 2 menjelaskan alur pada proses pencarian algoritma Knuth-Morris-Pratt, dimana proses awal yang dilakukan yaitu memasukkan pattern di dalam text yang tersedia. Proses pencarian dimulai dari karakter paling kiri ke kanan pattern, setiap karakter akan dibandingkan satu per satu, jika terjadi ketidakcocokkan maka akan dicek nilai shift $[i]$ dan bergeser sesuai dengan nilai shift $[i]$, dan jika terjadi kecocokkan maka mengeluarkan hasil pencarian dan selesai.

\section{Hasil dan Pembahasan}

\subsection{Hasil Penelitian}

Hasil dari implementasi algoritma Knuth-Morris-Pratt dalam proses pencarian hadis yaitu sistem pencarian pada tujuh kitab hadis menggunakan algoritma Knuth-Morris-Pratt. Sistem pencarian hadis adalah sebuah sistem yang memiliki tujuan untuk mempermudah pencarian hadis, mempercepat waktu pencarian hadis dan dapat memberikan informasi rinci terkait hadis sesuai spesifikasi yang diinginkan oleh para pengguna yang membutuhkan informasi mengenai hadis. Penelitian dilakukan untuk mengimplementasikan algoritma Knuth-Morris-Pratt untuk melakukan pencarian. Proses pencarian dapat dilihat pada Gambar 3. 


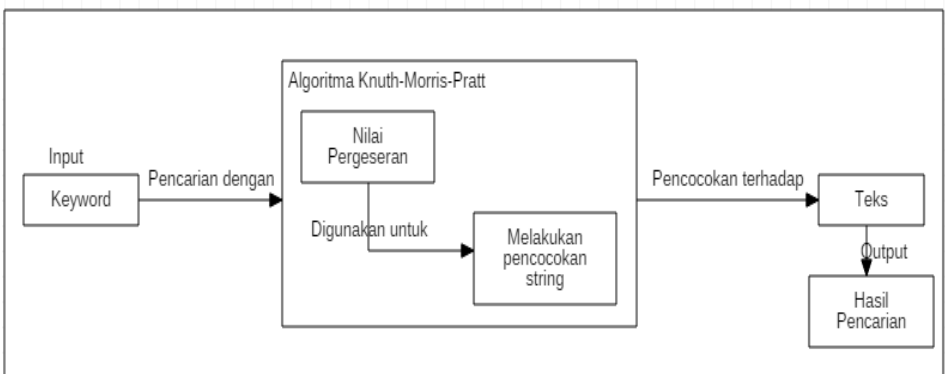

Gambar 3. Proses Pencarian Menggunakan Algoritma Knuth-Morris-Pratt.

Gambar 3 menggambarkan proses pencarian menggunakan algoritma Knuth-Morris-Pratt. Algoritma ini membagi proses pencarian dengan dua tahap yaitu proses mencari nilai pergeseran dari masing-masing karakter pada keyword yang dimasukkan user, dan proses pencocokkan karakter keyword yang telah memiliki nilai pergeseran pada teks yang tersedia dalam database.

\subsection{Tahap Pre-KMP}

Tahap Pre-KMP (Pre-Knuth-Morris-Pratt) merupakan suatu tahap pemberian nilai pergeseran terhadap keyword yang dimasukkan oleh user. Pemberian nilai ini dilakukan sebelum algoritma memulai pencocokkan string kedalam database, keyword yang dimasukkan akan dipecah menjadi array karakter. Tahap pre-KMP ini dapat mencegah pergeseran yang tidak berguna, proses preKMP hanya bergantung pada karakter yang ada di dalam pattern, tidak bergantung kepada karakter di dalam teks. Proses pemberian nilai pada proses pre-KMP dapat dilihat pada Gambar 4.

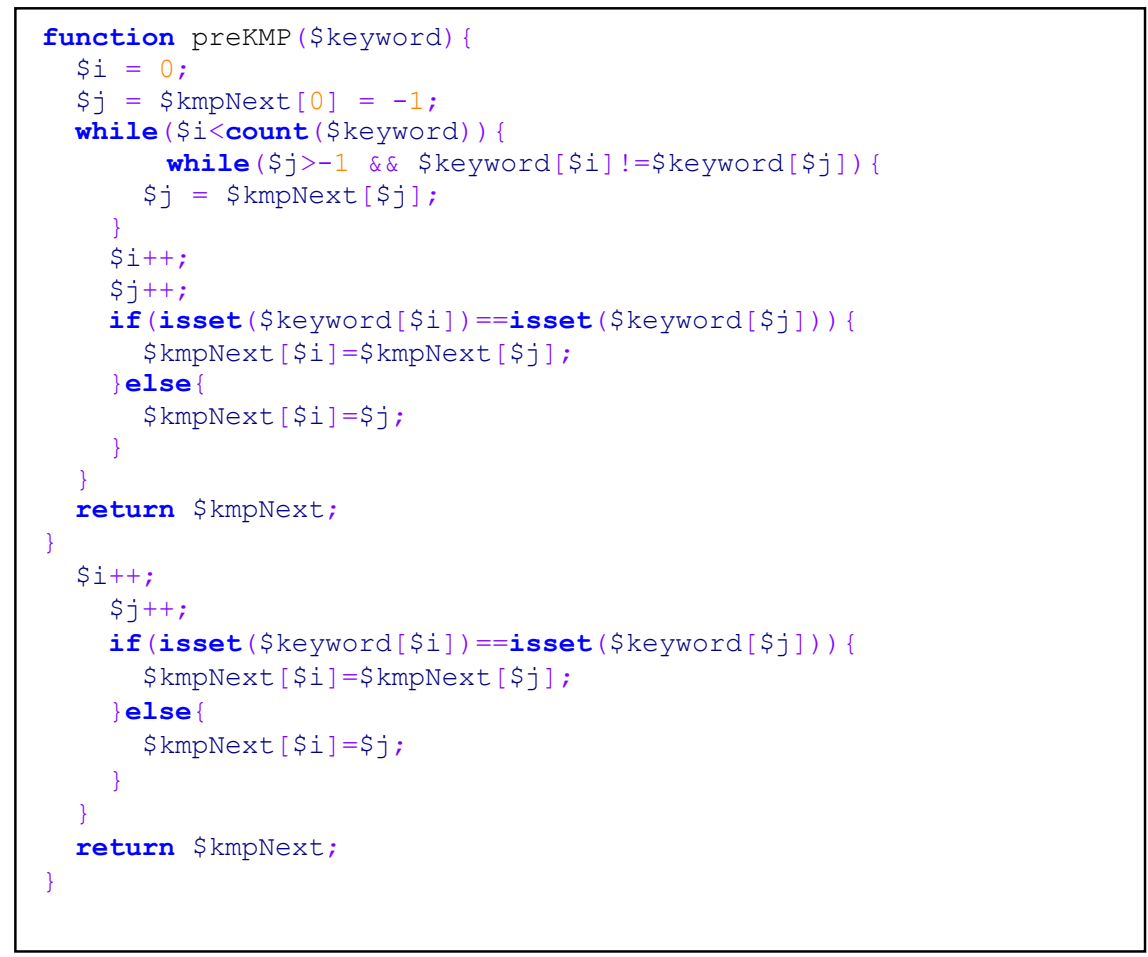

Gambar 4. Tahap pre-KMP.

Tahap pre-KMP ini menghasilkan nilai kmpNext untuk masing-masing karakter pada array keyword yang dimasukkan oleh user. Nilai kmpNext tersebut selanjutnya akan digunakan sebagai nilai lompatan pergeseran pada tahap selanjutnya yaitu tahap KMP-Search. 


\subsection{Tahap KMP-Search}

Tahap kedua setelah tahap pre-KMP pada algoritma Knuth-Morris-Pratt adalah tahap KMPSearch. Tahap ini merupakan proses pencocokkan string yang dimasukkan user yang telah dipecah menjadi array dan memiliki nilai pergeseran setiap karakternya, terhadap data hadis yang terdapat pada database. Proses pencarian pada tahap KMP-Search dapat dilihat pada Gambar 5.

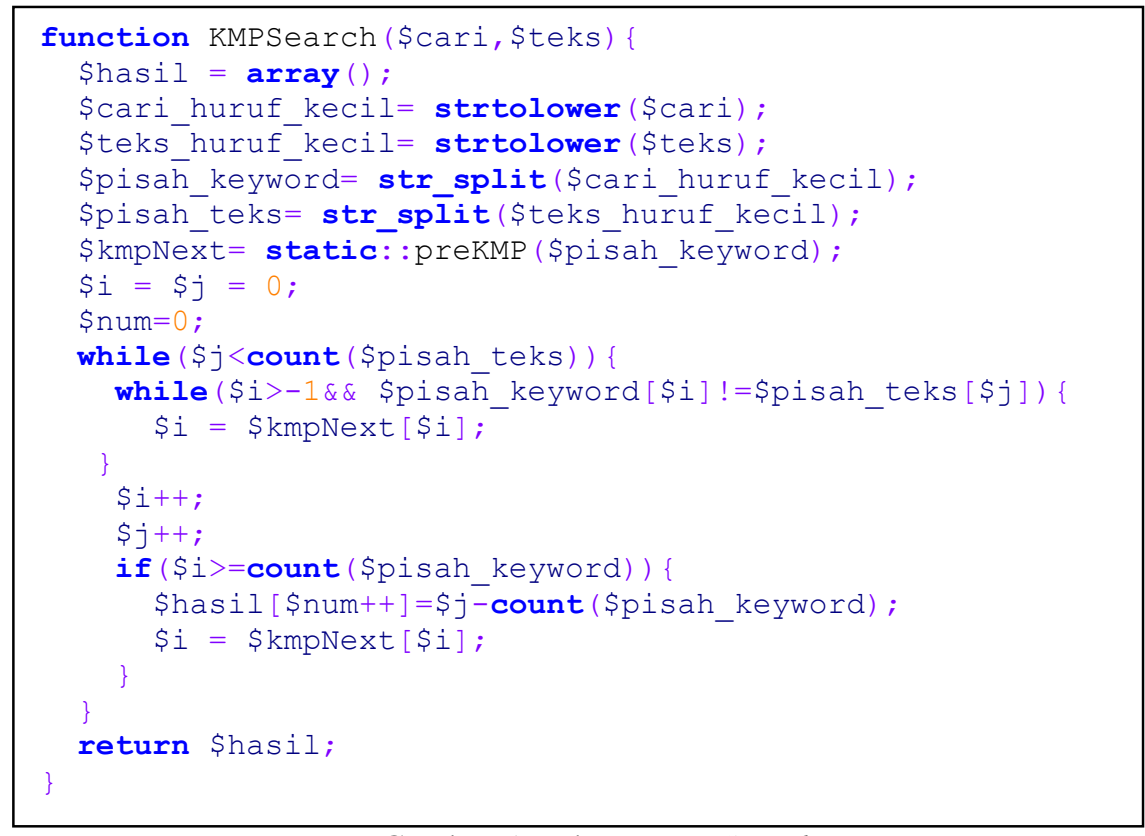

Gambar 5. Tahap KMP-Search.

Fungsi KMP yang telah dibuat kemudian dipanggil melalui Controller untuk melakukan pencarian seperti pada Gambar 6.

\$Isi_Indonesia $=$ \$this->kmp-> KMPSearch $(\$$ cari, $\$$ value $->$

Isi_Indonesia);

Gambar 6. Pemanggilan Fungsi KMP-Search

Gambar 6 menunjukkan pemanggilan fungsi KMP-Search pada variabel Isi_Indonesia untuk melakukan pencocokkan karakter antara keyword yang dimasukkan user yang ditampung pada variabel cari dengan data pada database yang ditampung pada variabel Isi_Indonesia.

Tahap ini digunakan untuk mendapatkan hasil pencarian dari keyword yang dimasukkan user terhadap data yang ada pada database. Data hasil pencarian kemudian ditampilkan kepada user sebagai hasil pencarian yang ditemukan.

\subsection{Tampilan Form Pencarian}

Tampilan pada sistem pencarian hadis pada tujuh kitab hadis ini dibuat dengan menampilkan form pencarian dengan pilihan kitab berupa pilihan checkbox, sehingga user bebas untuk memilih jumlah kitab yang akan dicari. keyword dimasukkan setelah memilih kitab yang akan dicari pada form yang telah disediakan. Form pencarian dapat dilihat pada Gambar 7. 




\subsection{Tampilan Hasil Pencarian}

Tampilan hasil pencarian pada sistem pencarian hadis pada tujuh kitab hadis ini dibuat dengan menampilkan hasil pencarian dengan keterangan kitab, sehingga user dapat mengetahui perawi dari hadis yang ditampilkan. Form hasil pencarian pada kata "surga" dapat dilihat pada Gambar 8.

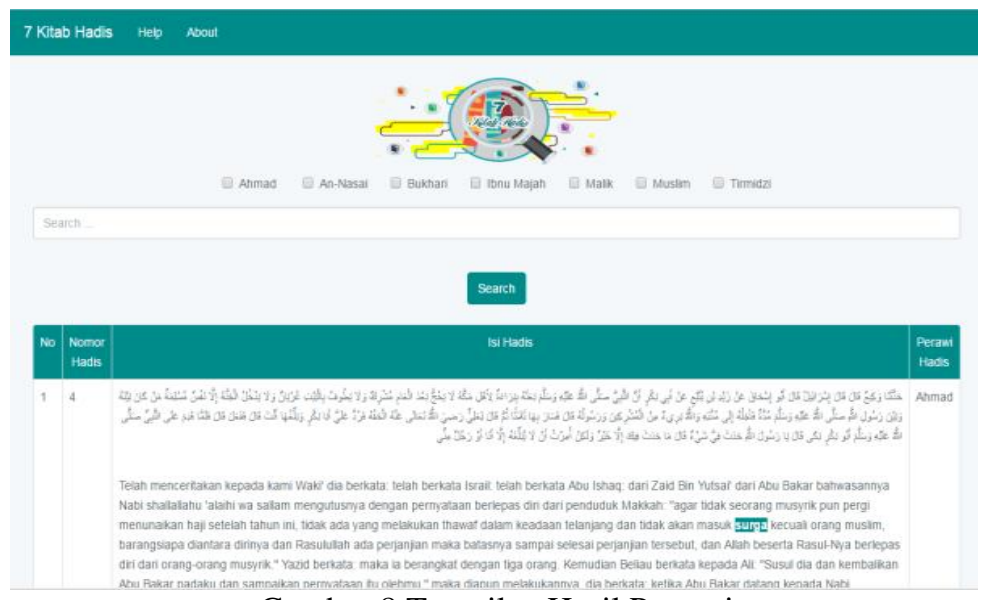

Gambar 8 Tampilan Hasil Pencarian.

\subsection{Pengujian}

Pengujian sistem yang dilakukan pada penelitian ini yaitu menguji apakah data dapat ditemukan pada saat proses pencarian menggunakan algoritma Knuth-Morris-Pratt, kemudian akan dibandingkan antara jumlah data yang ditemukan saat pencarian dengan algoritma dengan jumlah data yang ditemukan saat menggunakan query pada database. Hasil pengujian pencarian menggunakan query pada database dan pencarian menggunakan sistem dapat dilihat pada Tabel 1, Tabel 2, dan Tabel 3.

TABEL 1 Hasil Pencarian Dan Rata-Rata Waktu Pencarian Satu Kata

\begin{tabular}{clcc}
\hline No & Kata yang dicari & Jumlah ditemukan (Tujuh kitab) & Rata-rata waktu Pencarian (Detik) \\
\hline 1 & Puasa & 2181 & 0.066000692 \\
2 & Haji & 1933 & 0.065333683 \\
3 & Zakat & 794 & 0.066967628 \\
4 & Surga & 2524 & 0.066000619 \\
5 & Amal & 1762 & 0.065666968 \\
\hline
\end{tabular}


Tabel 1 menunjukkan hasil pencarian yang diperoleh dengan kata yang dicari yaitu Puasa, Haji, Zakat, Surga, dan amal. Kelima kata tersebut dicari sebanyak sembilan kali untuk mendapatkan rata-rata waktu pencarian.

Pencarian pada tujuh kitab hadis menghasilkan 2181 hadis yang mengandung kata "Puasa" dengan rata-rata waktu pencarian 0.066000692 detik, 1933 hadis yang mengandung kata "Haji" dengan rata-rata waktu pencarian 0.065333683 detik, 794 hadis yang mengandung kata "Zakat" dengan rata-rata waktu pencarian 0.066967628 detik, 2524 hadis yang mengandung kata "Surga" dengan rata-rata waktu pencarian 0.066000619 detik, dan 1762 hadis yang mengandung kata "Amal" dengan rata-rata waktu pencarian 0.065666968 detik.

TABEL 2 Hasil Pencarian Dan Rata-Rata Waktu Pencarian Dua Kata

\begin{tabular}{clcc}
\hline No & Kata yang dicari & Jumlah ditemukan (Tujuh kitab) & Rata-rata waktu Pencarian (Detik) \\
\hline 1 & Matahari Terbenam & 172 & 0.076333690 \\
2 & Puasa Sunnah & 14 & 0.074667632 \\
3 & Terbit Fajar & 68 & 0.075000664 \\
4 & Hari Raya & 256 & 0.074334326 \\
5 & Membayar Zakat & 74 & 0.075200642 \\
\hline
\end{tabular}

Tabel 2 menunjukkan hasil pencarian yang diperoleh dengan kata yang dicari yaitu Matahari Terbenam, Puasa Sunnah, Terbit Fajar, Hari Raya, dan Membayar Zakat. Kelima kata tersebut dicari sebanyak sembilan kali untuk mendapatkan rata-rata waktu pencarian.

Pencarian pada tujuh kitab hadis menghasilkan 172 hadis yang mengandung kata "Matahari Terbenam" dengan rata-rata waktu pencarian 0.076333690 detik, 14 hadis yang mengandung kata "Puasa Sunnah" dengan rata-rata waktu pencarian 0.074667632 detik, 68 hadis yang mengandung kata "Terbit Fajar" dengan rata-rata waktu pencarian 0.075000664 detik, 256 hadis yang mengandung kata "Hari Raya" dengan rata-rata waktu pencarian 0.074334326 detik, dan 74 hadis yang mengandung kata "Membayar Zakat" dengan rata-rata waktu pencarian 0.075200642 detik.

TABEL 3 Hasil Pencarian Dan Rata-Rata Waktu Pencarian Tiga Kata

\begin{tabular}{clcc}
\hline No & \multicolumn{1}{c}{ Kata yang dicari } & Jumlah ditemukan (Tujuh kitab) & $\begin{array}{c}\text { Rata-rata waktu Pencarian } \\
\text { (Detik) }\end{array}$ \\
\hline 1 & Hanya Kepada Allah & 16 & 0.079334264 \\
2 & Sebelum Matahari Terbenam & 18 & 0.085333656 \\
3 & Dalam Api Neraka & 16 & 0.075667213 \\
4 & Seorang Budak Perempuan & 46 & 0.085000682 \\
5 & Bekas Perjalanan Jauh & 1 & 0.084667452 \\
\hline
\end{tabular}

Tabel 3 menunjukkan hasil pencarian yang diperoleh dengan kata yang dicari yaitu Hanya Kepada Allah, Sebelum Matahari Terbenam, Dalam Api Neraka, Seorang Budak Perempuan, Bekas Perjalanan Jauh. Kelima kata tersebut dicari sebanyak sembilan kali untuk mendapatkan rata-rata waktu pencarian.

Pencarian pada tujuh kitab hadis menghasilkan 16 hadis yang mengandung kata "Hanya Kepada Allah" dengan rata-rata waktu pencarian 0.079334264 detik, 18 hadis yang mengandung kata "Sebelum Matahari Terbenam" dengan rata-rata waktu pencarian 0.085333656 detik, 16 hadis yang mengandung kata "Dalam Api Neraka" dengan rata-rata waktu pencarian 0.075667213 detik, 46 hadis yang mengandung kata "Seorang Budak Perempuan" dengan rata-rata waktu pencarian 0.085000682 detik, dan satu hadis yang mengandung kata "Bekas Perjalanan Jauh" dengan rata-rata waktu pencarian 0.084667452 detik. 
Rata-rata waktu pencarian dipengaruhi oleh panjang teks dan keyword (pattern) yang dicari oleh user. Semakin panjang keyword (pattern) dan teks pada database maka waktu pencarian akan meningkat, semakin sedikit keyword (pattern) dan teks pada database maka waktu pencarian akan semakin sedikit atau semakin cepat.

\section{Simpulan}

Simpulan yang diperoleh berdasarkan hasil pengujian dan analisis pada sistem pencarian pada tujuh kitab hadis menggunakan algoritma Knuth-Morris-Pratt adalah sebagai berikut:

1. Sistem pencarian pada tujuh kitab hadis menggunakan algoritma Knuth-Morris-Pratt berguna untuk menemukan hadis sesuai dengan yang dicari berdasarkan perawinya.

2. Algoritma Knuth-Morris-Pratt dapat diimplementasikan pada proses pencarian hadis.

3. Data yang disediakan sistem terdiri dari tujuh kitab hadis yaitu:
a. Kitab Ahmad dengan jumlah data 26.363 hadis.
b. Kitab An-nasa'i dengan jumlah data 5.662 hadis.
c. Kitab Bukhari dengan jumlah data 7.008 hadis.
d. Kitab Ibnu Majah dengan jumlah data 4.332 hadis.
e. Kitab Malik dengan jumlah data 1.594 hadis.
f. Kitab Muslim dengan jumlah data 5.362 hadis.
g. Kitab Tirmidzi dengan jumlah data 3.891 hadis. Dengan total jumlah hadis yaitu 52.618 hadis.

4. Panjang karakter teks pada database dan pattern yang dimasukkan oleh user mempengaruhi waktu pencarian, semakin panjang teks pada database dan pattern yang dimasukkan oleh user maka waktu pencarian yang dibutuhkan akan semakin lama.

\section{Referensi}

[1] Anam, Syamsu. Analisa Kinerja Search Engine Dengan Menilai Precision And Recall Untuk Informasi Marketing Dan Advertising (Studi Kasus: Google, Yahoo, MSN, Ask). Skripsi. Universitas Narotama Surabaya. Surabaya (2008)

[2] Charras, C. Lecroq, T. Handbook of Exact String-Matching Algorithms. London. King's College Publications (2004)

[3] Cooperman, Alan. Brian, J, Grim. Mehtab, S, Karim. Sahar, Chaudhry. Mapping The Muslim Global Muslim Population. Washington D.C. Pew Forum on Religion \& Public Life (2009)

[4] Ervana, A. dan Pertiwi, A. Implementasi Algoritma Pencocokan String pada Aplikasi Pengarsipan Berbasis Web. Jurnal Informatika. vol. 3, pp. 3-4 (2012)

[5] Wibowo, Thio. Wibowo, Ardianto. Sari, Rika Perdana. Pembuatan Aplikasi Untuk Mendeteksi Kebenaran Perintah Sql Query Menggunakan Metode Knuth-Morris Pratt (KMP). Jurnal Teknik Informatika. vol. 1. pp. 3-5 ( 2012) 